\title{
PENERAPAN METODE PROBLEM SOLVING UNTUK MENINGKATKAN PRESTASI BELAJAR SISWA KELAS XI-MIA2 POKOK BAHASAN DINAMIKA PERAN INDONESIA DALAM PERDAMAIAN DUNIA PADA SMA NEGERI 1 KEMBANG TANJONG
}

\author{
Lilis Suryani
}

SMA Negeri 1 Kembang Tanjong

Email: Lilisuryani656@gmail.com

\begin{abstract}
ABSTRAK
Penelitian ini dilakukan di SMA Negeri 1 Kembang Tanjong selama tiga bulan sejak bulan Februari sampai April 2019 bertujuan untuk meningkatkan prestasi belajar siswa kelas XI-MIA2 pokok bahasan dinamika peran Indonesia dalam perdamaian dunia melalui penerapan metode problem solving pada SMA Negeri 1 Kembang Tanjong. Metode penelitian yang digunakan adalah penelitian tindakan kelas yang terdiri dari 2 siklus. Subjek penelitian adalah siswasiswiKelas XI-MIA2 SMA Negeri 1 kembang Tanjong tahu pelajaran 2018/2019 sebanyak 21 orang. Analisis data menggunakan teknik analisis deskriptif komparatif dengan membandingkan kondisi awal dengan hasil-hasil yang dicapai pada setiap siklus, dan analisis deskriptif kualitatif hasil observasi dengan membandingkan hasil observasi dan refleksi pada siklus I dan siklus II. Persentase ketuntasan yang diperoleh pada siklus I sebesar $61,9 \%$ dengan nilai rata-rata kelas sebesar 68,6 dan meningkat pada siklus II menjadi 90,5\% dengan nilai rata-rata kelas 78,1. Pada kedua siklus ini terjadi perubahan aktivitas dan perolehan nilai yang signifikan bila dibandingkan dengan pra siklus dengan ketuntasa belajar yang hanya mencapai $42,9 \%$ dan nilai rata-rata adalah 61,4. Dengan demikian, melalui penerapan metode problem solving dapat meningkatkan prestasi belajar siswa kelas XI-MIA2 pada pokok bahasan dinamika peran Indonesia dalam perdamaian dunia pada SMA Negeri 1 Kembang Tanjong

Kata Kunci : Prestasi Belajar, Metode Problem Solving, Dinamika Peran Indonesia dalam Perdamaian Dunia
\end{abstract}

\section{Pendahuluan}

Pendidikan kewarganegaraan merupakan mata pelajaran yang bertujuan mendidik siswanya untuk membina moral dan menjadikan warga negara yang baik, yang diharapkan diwujudkan dalam kehidupan sehari-hari, baikdi lingkungan sekolah maupun di luar lingkungan sekolah. Pendidikan kewarganegaraan merupakan mata pelajaran yang penting bagi siswa bak secara formal maupun secara ilmu. Fungsi pembelajaran pendidikan kewarganegaraan itu sendiri sebagai wahana mendorong keaktifan atau partisipasi dan berpikir cerdas dengan mengoptimalkan kreatifitas yang dimiliki oleh setiap siswa.

Peranan guru sangatlah penting dalam menciptakan masyarakat yang terdidik, dengan merubah gaya belajar pada siswa di dalam kelas. Sekarang ini metode ceramah sudah tidak dapat digunakan lagi dalam mata pelajaran pendidikan kewarganegaraan, karena metode tersebut sudah tidak cocok lagi terutama untuk mata pelajaran pendidikan kewarganegaraan, metode ceramah sangatlah membosankan sehingga siswa cenderung pasif dan merasa bosan dengan metode satu arah tersebut, hal ini bisa berakibat kepada rendahnya pencapaian hasil belajar.

Dari hasil ulangan harian Pendidikan kewarganegaraan sebanyak 21 orang siswa SMA Negeri 1 Kembang Tanjong, hanya 9 orang siswa atau $42,9 \%$ yang memperoleh ketuntasan belajar, sedangkan 12 Orang atau $57,1 \%$ siswa memperoleh nilai di bawah KKM (Kriteria Ketuntasan Minimal). Karena itulah, penulis tertarik untuk 
Jurnal Sains Riset (JSR)

$p$-ISSN 2088-0952, $e$-ISSN 2714-531X

melakukan penelitian ini.

\section{Metode Penelitian}

Penelitian ini dilaksanakan di SMA Negeri 1 Kembang Tanjong di Kelas XIMIA2 pada pokok bahasan dinamika peran Indonesia dalam Perdamaian dunia. Penelitian ini dilaksanakan selama 3 bulan yaitu bulan Februari sampai April 2019. Pelaksanaan penelitian dilakukan pada harihari efektif sesuai dengan jadwal jam pelajaran. Subjek penelitian adalah siswasiswi kelas XI-MIA2 tahun pelajaran 2018/2019, terdiri dari 9 orang siswa dan 12 orang siswi. Data yang diperoleh berasal dari siswa kelas XI-MIA2 SMA Negeri 1 kembang Tanjong dan guru/teman sejawat yang merupakan guru kolaborasi dalam kegiatan penelitian ini. Alat pengumpul data yang digunakan adalah lembar instrumen aktifitas siswa dalam PBM, lembar instrumen PBM guru dan butir soal tes.

Analisis data menggunakan analisis deskriptif komparatif dan kualitatif. Analisis deskriptif komparatif dengan rumus :

$$
\mathrm{PHB}=\frac{P}{Q} \mathrm{X} 100 \%
$$

Dengan kriteria ketuntasan belajar adalah : $0 \%<\mathrm{PHB}<70 \%$

Selanjutnya dihitunz persentase siswa yang telah tuntas dalam belajar secara klasikal menggunakan rumus :

$$
\mathrm{PHB}=\frac{X}{Y} \mathrm{X} 100 \%
$$

Kriteria ketuntasan belajar secara klasikal akan diperoleh jika di dalam kelas tersebut terdapat $85 \%$ siswa telah mencapai nilai $\geq 70 \%$.

Analisis deskriptif kualitatif hasil observasi dengan cara membandingkan hasil observasi dan refleksi pada siklus I dan II dengan menggunakan rumus :

$$
\mathrm{P}=\frac{F}{N} \mathrm{X} 100 \%
$$

\section{Hasil Penelitian Dan Pembahasan Deskripsi Kondisi Awal}

Berdasarkan hasil ulangan harian nilai belajar pada pra siklus dapat dianalisa sebagai berikut :

1. Nilai rata-rata kelas sebesar 61,4 dengan pencapaian ketuntasan 9 orang siswa atau $42,9 \%$ siswa yang mempunyai nilai di atas KKM. Sedangkan 12 orang atau $57,1 \%$ siswa memperoleh nilai di bawah KKM.

2. Secara klasikal siswa belum mencapai ketuntasan belajar.

\section{Deskripsi Hasil Siklus I}

1. Hasil belajar siswa

Tabel : Hasil Belajar Siswa Siklus I

\begin{tabular}{|l|l|c|c|}
\hline \multirow{2}{*}{ No } & \multirow{2}{*}{ Ketuntasan } & Jumlah & $\begin{array}{l}\text { Persentase } \\
(\%)\end{array}$ \\
\cline { 3 - 4 } & & 13 & 61,9 \\
\hline 1. & Tuntas & 8 & 38,1 \\
\hline & $\begin{array}{l}\text { Tidak } \\
\text { Tuntas }\end{array}$ & \multicolumn{2}{|c|}{21} \\
\hline \multicolumn{2}{|c|}{ Jumlah siswa } & \multicolumn{2}{|c|}{68,6} \\
\hline \multicolumn{2}{|c|}{ Rata-rata kelas } & \multicolumn{2}{c}{} \\
\hline
\end{tabular}

2. Aktivitas siswa pada pertemuan pertama masih banyak yang kurang dengan persentase sebsesar 29,09\%, pada pertemuan kedua aktivitas siswa meningkat $12,73 \%$ menjadi $41,82 \%$ dengan kriteria cukup.

3. Aktivitas guru memperoleh persentase sebesar $45 \%$ pada pertemuan pertama dengan masih banyak yang termasuk kriteria cukup, akan tetapi seagian kecil aspek pengamatan memperolehkriteria baik. Aktivitas guru meningkat pada pertemuan kedua menjadi baik dengan persentase sebesar $62,5 \%$.

\section{Deskripsi Hasil Siklus II}

1. Hasil belajar siswa

Tabel : Hasil Belajar Siswa Siklus II

\begin{tabular}{|l|l|c|c|}
\hline \multirow{2}{*}{ No } & Ketuntasan & \multicolumn{2}{|c|}{ KKM 70 } \\
\cline { 3 - 4 } & Jumlah & $\begin{array}{l}\text { Persentase } \\
(\%)\end{array}$ \\
\hline 1. & Tuntas & 19 & 90,5 \\
\hline 2. & $\begin{array}{l}\text { Tidak } \\
\text { Tuntas }\end{array}$ & 2 & 9,5 \\
\hline \multicolumn{2}{|c|}{ Jumlah siswa } & \multicolumn{2}{|c|}{21} \\
\hline \multicolumn{2}{|c|}{ Rata-rata kelas } & \multicolumn{2}{|c|}{78,1} \\
\hline
\end{tabular}


2. Aktivitas siswa pada pertemuan ketiga termasuk kategori cukup dengan persentase sebsesar 49,9\%, pada pertemuan keempat aktivitas siswa meningkat menjadi sangat baik dengan persentase $80 \%$

3. Aktivitas guru memperoleh persentase sebesar $63,75 \%$ pada pertemuan ketiga termasuk dalam kategori baik, pada pertemuan keempat meningkat menjadi sangat baik dengan persentase sebesar $82,5 \%$.

\section{PENUTUP}

Berdasarkan hasil penelitian, dapat disimpulkan bahwa melalui penerapan metode problem solving dapat meningkatkan prestasi belajar siswa kelas XI-MIA2 pokok bahasan dinamika peran Indonesia dalam perdamaian dunia pada SMA Negeri 1 Kembang Tanjong. Peningkatan kemampuan belajar siswa tersebut terlihat dalam hal meningkatnya nilai rata-rata, persentase ketuntasan siswa dan juga suasana belajar siswa yang berbeda dari suasana belajar sebelum dilakukan tindakan.

\section{Daftar Pustaka}

Ahmadi, Abu. 1997. Strategi Belajar Pendidikan. Bandung: Pustaka Setia.

Anas, Sudijono. 2005. Pengantar Evaluasi Pendidikan. Jakarta: PT. Raja Grafindo Persada.

Aqib Zainal. 2009. Penelitian Tindakan Kelas Untuk Guru. Bandung: Yrama Widya.

Hamalik, Oemar. 2008. Pendekatan Belajar Pendidikan Lingkungan. Jakarta: Bumi Aksara.

Slameto. 2003. Belajar dan Faktor-faktor yang Mempengaruhinya. Bandung: PT. Rineka Cipta.

Usman, Unzir. 1993. Upaya Optimalisasi Kegiatan Belajar Mengajar. Jakarta: Remaja Rosda Karya.

Winkel, WS. 1997. Psikologi Pendidikan dan Evaluasi Belajar. Jakarta: Gramedia. 